\title{
What hormones may regulate food intake in fish?
}

\author{
Pierre-Yves Le Bail (1) and Gilles Boeuf(2) \\ (1) Iaboratoire de Physiologie des Poissons, INRA, Campus de Beaulieu, 35042 Rennes, France. \\ Li-mail: pylb@beaulieu,rennes.inra.fr \\ (2) Laboratoire de Physiologie des Poissons, IHREMER, B.P. 70, 29280 Illonzané, France. \\ E-mail: ghoeuf@ifremer.fr
}

Received May 2, 1997; accepted October 23, 1997.

Le Bail P.-Y., G. Bouf. Aquat. Living Resour., 1997, 10, 371-379.

Abstract

This is an overview of the hormones which may be involved in food intake control in fish, and some hypothetical pathways of their action are given based on mammalian knowledge. Most of the observed effects of these hormones may result from four types of mechanisms, each hormone acting by one or several as follows: (1) hormones could have a direct effect on central nervous system centres, associated with food intake behaviour or via vagal afferent neurons; (2) an indirect effect may occur via the gut which slows gastrointestinal transit, thus resulting in stomach distention which activates vagal afferent neurons; (3) they could have an indirect effect, acting directly on intermediary metabolism via glucose, free fatty acids or amino acids mobilization or storage; (4) the last possible pathway is an indirect effect by modifying directly or indirectly secretions of other hormones involved in food intake control. Some of these hormones (CCK, PYY, glucagon, adrenalin) act as short-term factors which regulate meal ingestion and are generally inhibitory factors. On the other hand, other hormones $(\mathrm{GH}, \mathrm{TH}$, and leptin) require more time to modify food intake behaviour, and appear as stored calorie regulators. However, the orientation of hormones to short-term or to long-term action is not always clear as it has been noted for insulin and glucocorticoids, and may depend on the hormonal and metabolite environment.

Keywords: Food intake, hormones.

Quelles sont les hormones qui semblent impliquées dans la prise alimentaire des poissons?

Résumé

Cette synthèse donne un aperçu des hormones pouvant être impliquées dans le contrôle de la prise alimentaire des poissons et propose des voies d'action hypothétiques en se basant sur les connaissances acquises chez les mammifères. La plupart des effets observés tésulteraient de quatre types de mécanismes, chaque hormone agissant par le biais d'un ou de plusieurs d'entre eux : (1) les hormones peuvent agir directement sur les noyaux du système nerveux central associés au comportement alimentaire, ou via les afférents du nerf vague ; (2) elles peuvent agir indirectement via le tube digestif en ralentissant le transit gastro-intestinal, ce qui conduit à une distension de l'estomac activant les afférents du nerf vague ; (3) elles peuvent agir indirectement au niveau du métabolisme intermédiaire via la mobilisation ou le stockage du glucose, des acides gras libres ou des acides aminés ; (4) elles peuvent modifier directement ou indirectement sur la sécrétion d'autres hormones impliquées dans le contrôle de la prise alimentaire. Certaines de ces hormones (CCK, PYY, glucagon, adrénaline) agissent à court terme en régulant le niveau d'ingestion et sont généralement inhibitrices. D'autres hormones ( $\mathrm{GH}$, TH et leptin) demandent plus de temps pour modifier le comportement de prise alimentaire et apparaissent comme des régulateurs du stockage énergétique. Cependant, les actions à court ou à long terme de ces hormones ne sont pas toujours très claires, comme cela est observé pour les glucocorticoïdes et l'insuline, et semblent dépendre de l'environnement métabolique et hormonal.

Mots-clés : Prise alimentaire, hormones. 


\section{INTRODUCTION}

In vertebrates, food intake behaviour is controlled by the brain which receives information from different sources. Firstly, there are environmental influences such as social interactions, food quality and effort involved in aliment ingestion. Secondly memory, which permits food recognition. Thirdly, peripheral stimuli, including metabolic molecules such as glucose and hormones, can give information on the physiological status of animals.

Mechanisms which control satiety and food intake are complex, polyfactorial and are not yet clearly defined, even in mammals in which they have been studied for several decades. For several biological factors, it is difficult to separate their neuromediator, paracrine and endocrine effects, and for others, their hormonal status was not clearly established. In fish, if we don't take into account studies on lissuc localization of hormones and their plasma concentration changes, little information is available concerning hormone effect on food intake, or the mechanisms involved.

The aim of this brief revicw is to give an overview of the hormones which may be involved in food intake control in fish, and to give some hypothetical pathways of their action using mammalian knowledge. This noncxhaustive and schematic presentation takes its information from numerous reviews in which the reader will find more details.

\section{STIMULATING HORMONES}

\section{Thyroid hormones (TH)}

Thyroid follicles, present in the connective tissue of fish pharyngeal region, release essentially tetra-iodothyronine or thyroxine $\left(\mathrm{T}_{4}\right)$. The major source of triiodothyronine $\left(\mathrm{T}_{3}\right)$ comes from the enzymatic conversion of $\mathrm{T}_{3}$ by the removal of outer ring iodine by some peripheral tissues, through deiodinase action (reviews: Eales, 1985; Leatherland, 1994). $\mathrm{T}_{4}$ is considered to be the precursor of $\mathrm{T}_{3}$ which is the active hormone. Differently from mammals, plasma $T_{4}$ and $T_{3}$ are transported by other carrier proteins, mainly corresponding to lipoproteins in salmonids (Babin, 1992) which have a "buffering" effect on homeostatic control of free thyroid hormones. Thyroid hormones are involved in development, metamorphosis, growth and reproductive functions, as well as in general metabolism. In fish, they are among the most studied hormones, however their direct effects at the molecular level remain unclear.

Nutritional status has a strong influence on thyroid function in fish. The reduction of food ration, or fasting, decreases the sensitivity of the thyroid tissue to $\mathrm{TSH}$, and hepatic deiodinase activity. These two phenomena induce a decrease in circulating $\mathrm{T}_{3}$ and $\mathrm{T}_{4}$. In higher vertebrates, hepatic inner ring deiodinating type III activity increases in fasted animals, contributing to the decreased circulating $T_{3}$ level (Darras et al., 1995). $A$ recent and surprising result has been obtained by Sefkow et al (1996) who demonstrated in starved trout that $75-81 \%$ of all $\mathrm{T}_{3}$ was secreted by the thyroid, with only $19-25 \%$ resulting from $T_{4}$ to $T_{3}$ conversion, an opposite situation compared with fed fish (Eales and Brown, 1993). However, the drop in thyroid hormones normally occurs several days after the beginning of the treatment. Moreover, no relationship has been found between appetite, time of meal or level of food ration and $\mathrm{T}_{3}$ during a daily period (Farbridge and Leatherland, 1993; Gomez et al., 1997). None of these observations identify 'TH as having a short-term role in the control of food intake.

However, in some experiments, thyroid chronic treatment increased the voluntary food intake of fish (Donaldson et al., 1979). No more specific data are available in fish 10 aid our understanding of this potential effect of $\mathrm{TH}$. However, in mammals, $\mathrm{T}_{3}$ is well known to stimulate cell metabolism by increasing ATP consumption which needs more glucose. The decrease of plasma glucose observed after $\mathrm{T}_{4}$ injection in carp (Murat and Serfaty, 1971; Donaldson et al., 1979), suggests that $T_{3}$ may excrt its feeding action via a lower stimulation of the sympathetic system by the decrease of plasma carbohydrates. This possible pathway has to be established, taking into account the nutritional status of the fish, and the apparent opposite timing of the action on food intake of $T_{3}$ and glucose.

$\mathrm{T}_{3}$ specific binding sites have been recently discovcred in the olfactory epithelium and the brain (olfactory bulb, telencephalon, mid-brain and cerebellum) in migrating wild salmon (Kudo et al., 1994), suggesting, as in mammals, an important role in CNS and functional brain.

Lastly, as most aspects of the thyroid hormones influence intcrmediary metabolism, Leatherland (1994) suggested that $T_{3}$ could act as a permissive factor which would facilitate the direct action of other anabolic hormones involved in food intake control.

\section{Growth hormone (GH)}

The monomeric mature growth hormone $(\mathrm{GH})$ is a $22-k D a$ protein present in all vertebrates (review: Scanes and Campbell, 1995). It contains about 190 amino acids, but this number slightly varies between different GH species. Four cysteine residues are present that interact to form two disulfide bridges that link large and small peptide loops. The major sources of plasma GH (synthesis and secretion) are acidophil GH-secreting cells (somatotrophs) localized in the proximal Pars distalis of the adenohypophysis. Other very secondary sources are the brain and the immune system but these were not yet demonstrated in fish. GH receptors are present in almost all tissues, from mammals to fish, which have been studied. Growth hor- 
mone is involved in growth, osmoregulation and reproductive functions, as well as in carbohydrate, lipid, and protein metabolism.

In fish, a clear relationship exists between nutritional status and GH levels. Himick and Peter (1995) found that in goldfish plasma $\mathrm{GH}$ increased $30 \mathrm{~min}$ after the beginning of the meal. However, in our study on rainbow trout, we cannot find any relationship between diurnal GH fluctuations and the level of the food ration or the time of the daily meal (Gomez $e t$ al., 1996). So, the short term relationship between GH and nutrition remains unclear. This discrepancy observed between these experiments could be due to difference in the age or in the metabolic status of the fish, and status of lipid reserve.

Conversely, after a prolonged treatment, plasma GH increased when food ration size decreased and reached its highest values when fish were starved. This trend was observed in different fish species (Sumpter et al., 1991; Farbridge and Leatherland, 1992; Pérez-Sanchez et al., 1994; Peter and Marchant, 1995; Toguyeni et al., 1996). On the other hand, fat trout which had a very low plasma $\mathrm{GH}$ level, do not present an active feeding behaviour, even after several weeks of starvation (Le Bail et al. unpubl. data). So, high levels of GH may act as an appetite stimulatory factor. This hypothesis is supported by the fact that peripheral injections of $\mathrm{GH}$ stimulate food intake in mammals (review: Harvey et al., 1995a) and in several teleosts species (review: Donaldson et al., 1979; Le Bail et al., 1993, Peter and Marchant, 1995). The stimulatory effect of exogenous GH remains also effective in starved animals as this was demonstrated in Nile crocodiles (Crocodilus niloticus; Kimwele et al., 1992). Johnsson et al. (1994, 1996) suggested that, in rainbow trout, this increase of food intake was as a result of the $\mathrm{GH}$ stimulation of appetite and competitive ability.

Relationships between $\mathrm{GH}$ and carbohydrates are well documented in mammals (review: Harvey et al., 1995). GH can exert a diabetogenic effect and elevates the circulating concentration of glucose. In fact, $\mathrm{GH}$ reduces glucose uptake by adipose tissue in response to insulin. So, these data suggest that $\mathrm{GH}$, via the glucose pathway, may exert an inhibitory effect on food intake by its peripheral action. But this effect also may be inhibited by an increase of glucose which may block GH secretion. This glucose inhibition is reversible, according to the $\mathrm{GH}$ increase, observed after insulin injection in mammals as well as in fish (Fig. 1) (Rodgers et al., 1992; Gentil, 1996). In mammals, free fatty acids (FFA) also inhibit GH secretion (review: Harvey and Daughaday, 1995). So, after a meal, glucose and FFA plasma elevation participate in the decrease of $\mathrm{GH}$ secretion.

The action of GH may occur at the central level in reference to permeability of the blood-brain barrier to circulating $\mathrm{GH}$ since a central injection also increases feeding behaviour in mammals (Harvey 1995c). Moreover, GH receptors were detected in different brain

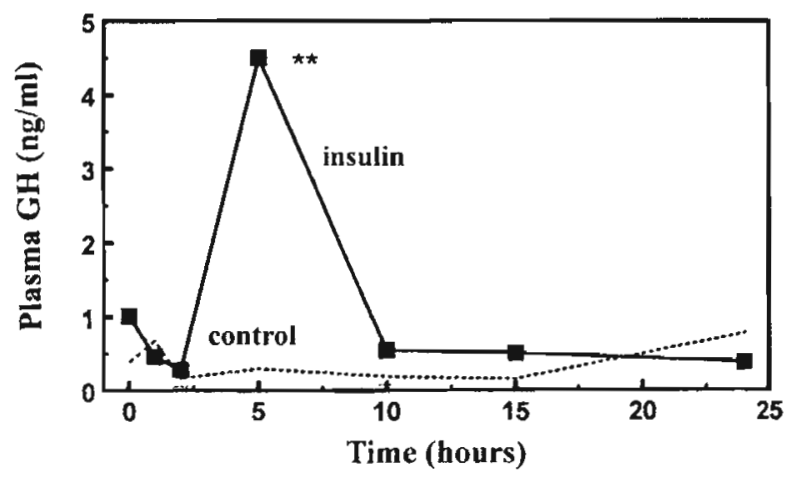

Figure 1. - Effect of insulin $\left(3 \mu \mathrm{g} \mathrm{kg}^{-1}\right)$ intravenous injection on plasma GH level in one catheterized rainbow trout (from Gentil, 1996).

regions, including those involved in feeding behaviour, in mammals, birds (Harvey and Hull, 1995) and fish (Gray et al., 1990; Sakamoto and Hirano, 1992; Yao et al., 1991, Pérez-Sanchez et al., 1992).

Control of food intake by GH in vive may be the result of the balance between its peripheral and central action, which is modified by the nutritional status of the fish, according to the following hypothesis: during a meal and shortly afterwards, high concentrations of FFA and glucose stimulate the satiety centre and inhibit the GH secretion and its central action on food intake. After a longer delay or during starvation, the decrease of plasma FFA and glucose induces an elevation of blood circulating $\mathrm{GH}$ which can increase the food intake behaviour. During this time, glucose released by $\mathrm{GH}$, from adipocytes and hepatocyles, is not sufficient to both stimulate the saticty centre and inhibit GH secretion. So, high levels of glucose, in parallel with low plasma levels of GH and vice versa, act in the same direction on feeding behaviour. However, the delay necessary to promote a resulting positive $\mathrm{GH}$ action on food intake behaviour has to be precised from the end of a meal to starvation.

\section{Insulin (short-term effects)}

Insulin is present in all vertebrates, from agnaths to mammals. This hormone is secreted by the endocrine pancreas which is organized as the "extrapancreatic" Brockmann body in many teleosts fish (review: Mommsen and Plisetskaya, 1991). It contains 51-58 amino acids which are organized into two chains (A and B) connected by disulfide bridges. In fish, as in mammals, insulin is an important regulator of carbohydrate, protein and lipid metabolism.

Plasma insulin levels are high in well fed fish or after a meal, and decrease in starved fish. It appears positively correlated with food ingested and negatively with feeding behaviour. These data suggest that insulin may also have a negative effect on food intake regulation. 
This hypothesis is not supported by the hungerinducing effect of an insulin injection previously observed in different mammals (Martin et al., 1984). More recently, Chang and Lin (1995) have induced an incrcase of feed consumption by tilapia, after insulin administration by immersion. In fact, the potential stimulatory effect of insulin is inhibited by the increase of glucagon (an inhibitory food intake factor) during the first part of the post-prandial period. Several hours after a meal, the glucagon/insulin ratio becomes low enough to permit the positive effect of insulin on the appetite.

Insulin secretion is, for the most part, positively regulated by circulating carbohydrates (glucose, galactose, mannose) and amino acids (arginine, lysine, leucine). Its possible short-term positive effect on food intake has been attributed to a decrease in blood carbohydrate levels: increase in plasma insulin levels after exogenous treatment results in a rapid reduction in the concentration of glucose in the plasma which directly stimulates the inhibitory feeding system in the brain or indirectly via the vagus afferent neurons.

\section{INHIBITORY HORMONES}

\section{Gut hormones}

\section{Cholecystokinine (CCK)}

In mammals and in birds, CCK is synthesized by different parts of the brain (CCK-8), in gut neurons and by endocrine cells (CCK-8, $-33,-39)$ of the upper small intestine (Reidelberger, 1994; Denbow, 1994; Figlewicz et al., 1996). CCK/gastrin - like peptides were detected in the gut and in the brain of numerous fish (Holmquist et al., 1979; Vigna et al., 1985, Sankaran et al., 1987; introduction: Himmick et al., 1993). Two types of receptors - Type A and Type B-gastrin were detected, but the saticty pathway utilises only, Type A. From mollusks to humans, numerous tissues contain Type A receptors such as the pancreas, gallbladder, pyloric sphincter, afferent vagal fibers and discrete areas in the brain known to be involved in food intake regulation (Morley, 1995).

Several observations support the important role of CCK in food intake control. Firstly, a relationship exists between nutritional status and peripheral CCK levels; Plasma CCK, secreted from the duodenum, increases during meals in many species and is, at least in part, dependent of phenylalanine and tyrosine plasma levels. Low levels of CCK observed in bulimic patients have been corrected when these patients were successfully treated with antidepressants. Sccondly, peripheral or intraventricular injections in the CNS of CCK provoked a decrease or a delay of food intake in mammals (Reidelberger, 1994; Figlewicz et al., 1996), birds (Denbow, 1994) and fish (Himick and Peter, 1994). In goldfish, this inhibition occurs $45 \mathrm{~min}$ following the injection. Lastly, in mammals, injections of
CCK antagonists restore food intake during its postprandial inhibition.

Thus, CCK appears to be a short term food intake regulator. It docs not seem to have a long-term effect on adiposity or on ingested food, because concomitant administration of CCK during meals decreases fond intake per meal, but also increases the number of meals in mammals.

The following hypothesis is the most agreed explanation for the mechanisms of peripheral CCK actions. During the ingestion of a meal, chyme entering the small intestine stimulates CCK secretion from the endocrine part of the upper intestine. Plasma CCK slows down gastric emptying, distends the stomach, activates the vagal afferent neurons, and inhibits the brain feeding system. Such an inhibition of gastric emptying by CCK was recently found in rainbow trout (Olssion et al., 1997).

However, several authors do not consider CCK as a satiety hormone, gives that physiological plasma levels are often one magnitude lower than the level necessary to produce the inhibition of food intake after exogenous CCK administration. So, it was proposed that food intake inhibition may result from vagal stimulation by paracrinc/ncurocrine $\mathrm{CCK}$ release from the upper intestine.

Endocrine and paracrine/neurocrine CCK inhibitory actions both support the hypothesis of a vagal pathway as an effector. However, these hypotheses cannot explain why, in vagotomized rats, the CCK receptor $B$ blockade of stimulates food intake. Taking these data into account, Reidelberg (1994) proposes that postprandial inhibition of food intake by CCK is duc in part to direct or indirect stimulation of vagal afferent neurons and also to a non-vagal mechanism which may act on a central or/and at peripheral sites. These peripheral CCK non-vagal pathways may use a hormonal relay system. It has been demonstrated that CCK modified secretion of insulin or GH in mammals (Harvey, 1995a, b) and fish (Himick et al., 1993; 1995). However, the importance of this last pathway remains to be studied.

It is interesting to note that peripheral administration of gastrin, which is a gut factor with a molecular structure similar to that of CCK, produces similar effects to those obtained by CCK (Denbow, 1994). However, its physiological role as a hormone controlling food intake is still unclear.

\section{Peptide Y Y (PYY)}

In mammals, PYY is a gut hormone, conversely to its structurally related peptide NPY which is distributed in central and peripheral neurons. It is a 36-amino acids peptide present in the endocrine cells in the lower small intestine, colon and in the plasma (review: Sheikh, 1991). PYY is known to act on blood flow, gut function and pancreas secretion. Related peptides were found in different fish species (review: Plisetskaya, 1990). They are localized in the endocrinological pancreas or the intestine (review: Duguay and Mommsen, 
1994). However, presence of a true PYY molecule has not yet been demonstrated in fish.

In mammals, after ingestion of a meal, PYY concentration increases significantly within 15-30 min and remains stable for several hours. PYY does not seem to have a direct effect on food intake. It acts as an inhibitor of satiety in several ways :

- PYY slows gastric emptying and retards jejunal and colonic motility. It appears as an "ideal break" in the gastrointestinal transit which would facilitate digestion and absorption. In this situation, stomach distention increases which possibly activates vagal afferent neurons, and inhibits brain feeding behaviour as observed for CCK.

- Some studies have demonstrated a PYY inhibitory effect on insulin secretion. Decreases in plasma insulin may contribute to a reduced animal appetite (sec above).

Thus, peripheral PYY seems to have an opposite effect compared with that of the central nervous system related peptide NPY which is known to increase food intake. However, we cannot exclude that PYY may act positively on food intake at brain level. In fish, NPY receptors, which equally recognize NPY and PYY, have been found in pituitary, and intraperitoneal injections of NPY have stimulated GH secretion which may increase food intake (Peter and Marchant, 1995). Endocrine PYY/NPY related peptides from peripheral sources have to be demonstrated in fish.

\section{Pancreatic hormones}

\section{Glucagon and GLP}

Glucagon, a peptide composed of 29 amino acids, is produced by endocrinological pancreatic A cells. Glucagon-like-peptide (GLP), containing 31 amino acids, is produced by the fish endocrinological pancreas and sometimes in the gut, as in agnathans (review: Duguay and Mommsen, 1994). In fish, as opposed to mammals, GLP acts at the liver level as a "superglucagon" but, at least in some cases, via other receptors and pathways. The principal action of these two types of hormones is glycogenolysis, in contrast to insulin.

Its action on food intake behaviour is supported by the two following observations: plasma glucagon increases during the postprandial period, in mammals as well in fish (Navarro et al., 1993), and in mammals, it has been demonstrated that peripheral or central injections of glucagon reduce food and protein intake (Bray, 1993).

The opposite mechanisms involved for insulin shortterm effects may occur for glucagon. Increases in glucagon plasma levels may induce higher plasma glucose levels which then stimulate inhibitory feeding systems directly in the brain or indirectly via the vagus afferent neurons. This mechanism may act in the short-term and does not seem to occur in starved fish, in which high plasma glucagon levels have been observed (Navarro et al., 1995). In fish, as a glucagon receptor has not yet been identified in the brain, it is unknown whether glucagon may have a direct effect at the CNS, as has been suggested for mammals (review: Bray, 1993).

\section{Insulin (long-term effects)}

In mammals, insulin receptors have been localized in specific nuclei (hypothalamus, limbic system), thought to be important in food intake behaviour. Also, it has been found that if the acute effect of peripheral insulin is anabolic, as seen above, a chronic elevation of insulin is catabolic (Figlewick et al., 1996). In this instance, it may result in a high caloric alimentation, insulin concentration subsequently increased in the central nervous system fluid, inducing in parallel an increase of energy expenditure, thus a decrease in food intake. In this case, the central action of insulin inhibits its peripheral lypogenic effect for limiting fish adiposity. This feeding behaviour is not observed after intraventricular injection of insulin in obese Zucker rats and may explain this pathology. Similarly, it has been observed in mammals that plasma insulin was positively correlated with adiposity. These data strongly suggest that insulin levels in cerebrospinal fluid reflect the level of food intake and the adiposity of the animal: a decrease in food intake, induced by insulin, may result in the augmentation of brain inhibitory factors such as CCK, CRF, dopamine and norepinephrine or in a decrease in NPY synthesis (Figlewick et al., 1996).

A similar phenomenon has been suggested in fish according to several observations:

- in adult salmonids, the strong positive correlation found between insulin and weight (Mommsen and Plisetskaya, 1991) may reflect an insulin/adipose relationship because, in this family, the animal adiposity increased with its size.

- The presence of insulin peptides in the brain was detected by immunocytochemistry whereas mRNA was undetectable (Plisetskaya et al., 1993). This result suggests that, as in mammals, insulin is produced only by endocrinological pancreas and it is then transported to the brain through the blood/cerebrospinal system.

- Finally, insulin specific receptors have been detected in the brain of several fish species (Mommsen and Plisetskaya, 1991).

\section{Cortisol and catecholamines}

Adrenalin is produced by the chromaffin tissue at the head kidney and secreted after stimulation by the sympathetic nervous system. This is considered as a fight-or-flight mechanism. Pituitary adrenocorticotropic hormone (ACTH) stimulates cortisol synthesis and secretion by inter-renal cells located in the head kidney, using cholesterol as a precursor. Cortisol stimulates lipid storage, protein lysis for neoglucogenesis and increases blood glucose. In fish, as in all vertebrates, plasma cortisol and catecholamines increase 
after acute or chronic stress (primary response). In parallel, inhibition of the feeding behaviour of the animal has been observed (reviews: Pickering, 1981; Wedemeyer et al., 1990).

Stimulation of lipolysis with liberation of FFA by catecholamines is far from clear, whereas their action on carbohydrate metabolism is well established, increasing glucogenolysis and neoglucogenesis which enhance plasma glucose levels (review: Mazeaud and Mazeaud, 1981). This increase in blood glucose may inhibit the food intake system, via the vagal afferent neuron of liver or directly via the CNS. In fact, injection of adrenalin has been shown to decrease food intake in avians (Denbow, 1994). In fish, the inhibitory effect of catecholamines on fond intake behaviour could be increased by its negative indirect effect via plasma carbohydrate, or direct effect on $\mathrm{GH}$ secretion (Peter and Marchant, 1995; see above).

The action of cortisol, as for catecholamines, may inhibit food intake via carbohydrates metabolism at the peripheral level in mammals as well as in fish (Vijayan and Leatherland 1989). However, in mammals, as for insulin, it may have an opposite effect when administrated into the CNS. At this level, glucocorticoids stimulate feeding and promote positive energy balance, possibly through an elevation of neuron NPY concentration (Figlewicz et al., 1996). So, glucocorticoids which increase with starvation in fish (Milne et al., 1979), may participate in the feeding behaviour. However, the balance between peripheral and central action has yet to be clarilied.

\section{Leptin}

It has long been thought that body fat deposits may have a mechanism to inform the brain to maintain the body wcight within a narrow range. For three years, such a signal was found to be a protein produced by the mouse obese gene (editorial: Steiner, 1996). Leptin is a protein composed of 167 amino acids, produced by adipose tissue of normal mice and humans. It is released into the blood and seems to cross the bloodbrain barrier because peripheral treatments are effective and plasma levels of leptin are positively correlated with leptin levels measured in the cerebral spinal fluid. Peripheral administration of leptin in some types of obese mice induce hypophagia and decreases adipose mass.

The central action of leptin is suggested by the presence of its receptors in several hypothalamic nuclei, having putative effects on satiety regulating centres. Leptin seems to interact with NPY because central administration inhibits the induction of the feeding behaviour stimulated by NPY. Moreover, peripheral administration of leptin inhibits the NPY expression.

However, Steiner (1996), taking into account the presence of leptin receptors in other tissues such as kidney, liver, the intestine and parts of the brain not involved in food intake regulation, has suggested that leptin effects on NPY expression were mediated not only directly by the brain, but also by a peripheral action. This may occur via glucocorticoids which stimulate NPY, according to the decrease of plasma corticosterone observed after leptin injection.

Recently, Sanson et al. (1996) demonstrated that a 35 amino acid fragment of leptin exerted significant inhibitory effects on ad libitum feeding in normal animals when injected centrally. This active peptide fragment, which can be easily synthesized, opens the way to investigate if it is also active in fish and if a leptin related peptide is present in lower vertebrates.

\section{OTHER FACTORS}

Other factors may significantly modify food intake behaviour in higher vertebrates, however their effect on feeding or their hormonal status are not clearly established. It is the case with calcitonin from thyroid tissue, sexual steroids from gonads, and numerous factors from the pancreas and gastrointestinal tract such as bombesin, gastrin releasing peptide (GRP), enterosta-

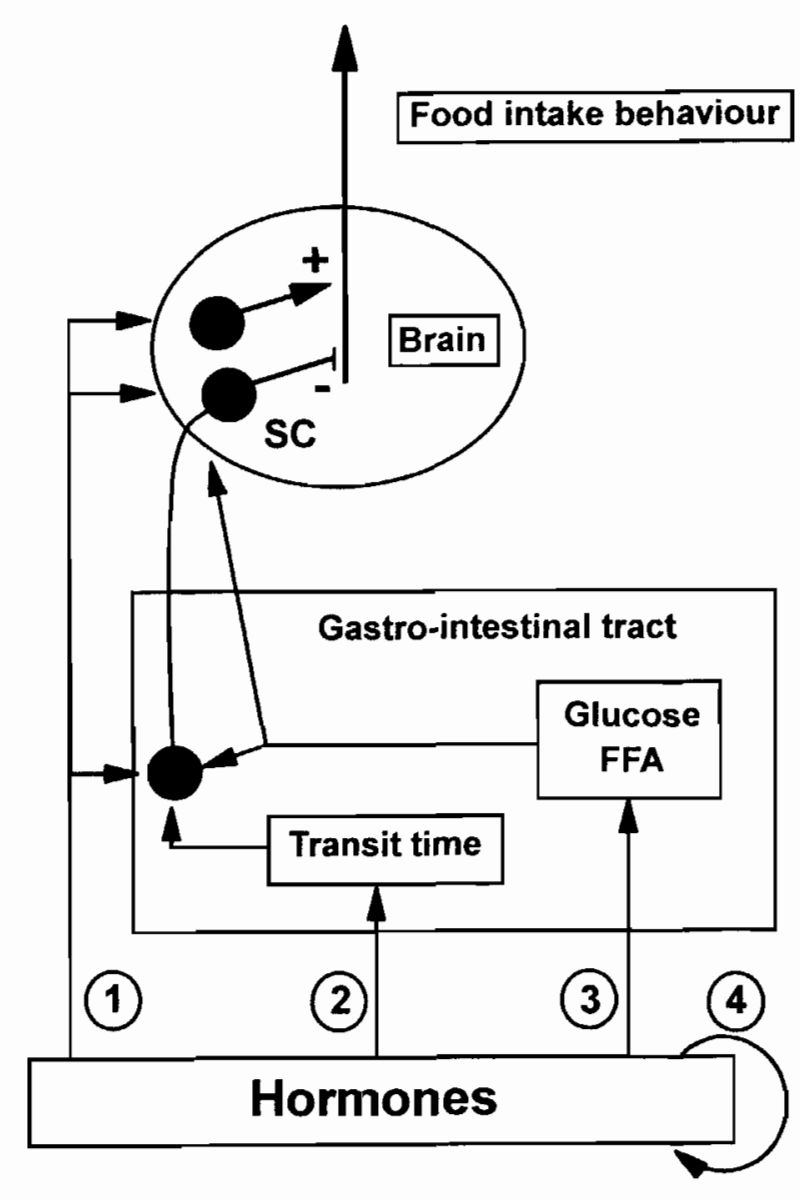

Figure 2. - Summary of the possible hormonal pathways involved in food intake bchaviour. 
tin, somatostatin (SRIF), gastrointestinal inhibitory peptide (GIP) and vasoaclive intestinal peptide (VIP). Most of these molecules act as inhibitory factors on food intake behaviour. They all remain to be studied in fish.

\section{CONCLUSION}

In this review, information concerning fish is very poor, fragmented, and most mechanisms of hormone effects are essentially hypothetical. Potential regulation of satiety, or food intake behaviour, by most of these hormones have to be definitely established in fish. Investigations will be long and difficult with respect to the variability between species and to the great number of hormones involved in feeding. Moreover, complex and multiple interactions exist between these hormones.

However, most of the observed effects of these hormones may result from four types of mechanisms (Fig. 2):

- direct effect on CNS centres, associated with food intake behaviour or via vagal afferent neurons (a good example is given by leptin);
- indirect effects on the gut which slows gastrointestinal transit, thus resulting in stomach distention which activates vagal afferent neurons (e.g. CCK);

- indirect effect, acting directly on intermediary metabolism via glucose, FFA or amino acids mobilization or storage; the modification of the plasma concentration of these metabolites may directly influence food intake behavioural centres in the CNS or via vagal afferent neurons (part of the insulin action uses this pathway);

- indirect effects, modifying directly or indirectly the secretion of other hormones involved in food intake control (this is the case the insulin on GH secretion).

Some of these hormones act as short-term factors which regulate meal ingestion. This is with the case of CCK, PYY, glucagon, and adrenalin which are generally inhibitory factors. On the other hand, other hormones require more time to modify food intake behaviour of the fish, and appear as stored calorie regulators. $\mathrm{GH}, \mathrm{TH}$, and leptin are in this category of factors. However, the orientation of hormone to shortterm or to long-term action is not as clear as it has been noted above for insulin and glucocorticoids, and may depend upon the hormonal and metabolite environment. It must be recognized that all these hormonal actions also interact with the endogenous brain control of food intake behaviour.

\section{Acknowledgements}

The authors wish to thank Dr Claudine Weil for kindly reviewing the manuscript. We are indebted to Eileen Lane for her kind help in the translation. These results were presented during the first COST 827 workshop on regulation of voluntary feed intake in fish, Aberdeen, 4-5 April 1997.

\section{REFERENCES}

Babin P.J. 1992. Binding of thyroxine and 3,5,3'-triiodothyronine to trout plasma lipoproteins. Am. J. Physiol. 262E, $712-720$.

Bray G.A. 1993. The nutrient balance hypothesis: peptides, sympathetic activity, and food intake. Ann. N. Y. Sci.679, 223-241.

Chang C.F., S.J. Lin 1995. Immersion in bovine insulin stimulates growth in tilapia. Reprod. Nutr. Dev. 35, 95-103.

Darras V.M., M. Cokelaere, E. Dewil, S. Arnouts, E. Decuypere, E.R. Kühn 1995. Partial food restriction increases hepatic inner ring deiodinating activity in the chicken and the rat. Gen. Comp. Endocrinol. 100, 334-338.

Denbow D.M. 1994. Peripheral regulation of food intake in poultry. J. Nutr. 124, 1349S-1354S.

Donaldson E.M., U.H.M. Fargerlund, D.A. Higg, J.R. McBride 1979. Hormonal enhancement of growth. In: Fish Physiology. W.S. Hoar, D.J. Randall, J.R. Brett eds. Academic Press, New York, VIII, 455-492.
Duguay F.J., T.P. Mommsen 1994. Molecular aspects of pancreatic peptides. In: Fish Physiology. A.P. Farrel, D.J. Randall eds. Academic Press, New York, XIII, 226-262.

Eales J.G. 1985. The peripheral metabolism of thyroid hormones and regulation of thyroidal status in poikilotherms. Can. J. Zool. 63, 1217-1231.

Eales J.G., S.B. Brown 1993. Measurement and regulation of thyroidal status in teleost fish. Rev. Fish Biol. Fish. 3, 299-347.

Farbridge K.J., J.F. Leatherland 1993. Relationship between appetite and plasma thyroid and growth hormone and metabolite concentration in rainbow trout, Oncorhynchus mykiss. In: Fish nutrition in practice. Biarritz (France), June 24-27, 1991, Les Colloques de l'INRA 61, 279-286.

Figlewicz D.P., M.W. Schwartz, R.J. Seeley, M. Chavez, D.G. Baskin, S.C. Woods, D. Porte 1996. Endocrine regulation of food intake and body weight. J. Lab. Clin. Med. 127, 328-332.

Gentil V. 1996. Production chez $E$. coli de l'IGF-II recombiné de truite arc-en-ciel (Oncorhynchus mykiss) et mise au point de son dosage radioimmunologique. Etude 
préliminaire de la régulation de la sécrétion de l'IGF-II chez la truite. Thèse dr. Univ. Rennes I, 182 p.

Gomez J.M., T. Boujard, G. Bocuf, A. Solari, P.-Y. Le Bail 1997. Individual nycthemeral plasma profiles of thyroid hormones in rainbow trout (Oncorhinchus mykiss) in relation with cortisol, growth hormone, and growth rate. Gen. Comp. Endocrinol. 107, 74-83.

Gomez J.M., T. Boujard, A. Fostier, P.-Y. Le Bail 1996. Characterization of growth hormone nycthemeral plasma profiles in catheterized rainbow trout (Oncorhynchus mykiss). J. Exp. Zool. 274, 171-180.

Gray E.S., G. Young, H.A. Bern 1990). Radioreceptor assay for growth hormone in coho salmon (Oncorhynchus kisutch) and its application to the study of stunting. J. Exp. Zool. 256, 29()-296.

Harvey S., K.L. Hull 1995. Growth hormone release, growth hormone receptors. In: Growth hormone, S. Harvey, C.G. Scanes, W.H. Daughaday eds. CRC Press, .303.335.

Harvey S., W.H. Daughaday 1995. Growth hormone release, profiles. In: Growth hormone. S. Harvey, C.G. Scanes, W.H. Daughaday eds. CRC Press, 193-223.

Harvey S. 1995a. Growth hormone release, Integrative hypothalamic control. In: (jrowth hormone. S. Harvey. C.G. Scanes, W.H. Daughaday eds. CRC Press, 131-162.

Harvey S. 1995h. Growth hormone release, Paracrine control. In: Growth hormone. S. Harvey, C.G Scanes, W.H Daughaday eds. CRC Press, 185-192.

Harvey S. 1995c. Growth hormone action, Neural fonction. In: Growth hormone. S. Harvey, C.G. Scanes, W.H. Daughaday eds. CRC Press, 437-449.

Himick B.A., R.E. Peter 1994. CCK/Gastrin-like immunoreactivity in brain and gut, and CCK suppression of feeding in goldfish. Am. J. Physiol. 267, R841-R851.

Himick B.A., R.E. Peter 1995. Neuropeptide regulation of feeding and growth hormone secretion in fish. Neth. J. Zool. 45, 3-9.

Himick B.A., A.A. Golosinski, A.-C. Jonsson, R.E. Peter 1993. CCK/Gastrin-like immunoreactivity in the goldfish pituitary, regulation of pituitary hormone secretion by CCK-like peptides in vitro. Gen. Comp. Endocrinol. 92. 88-103.

Holmquist A.L., G.L. Dockray, G.L. Rosenquist, J.H. Walsh 1979. Immunochemical characterization of cholecystokinin-like peptides in lamprey gut and brain. Gen. Comp. Endocrinol. 37, 474-481.

Johnsson J.I., B.Th. Björnsson 1994. Growth hormone increases growth rate, appetite and dominance in juvenil rainbow trout, Oncorhynchus mykiss. Anim. Behav. 48, 177-186.

Johnsson J.I., E. Jönsson, B.Th. Björnsson 1996. Dominance, nutritional state and growth hormone levels in rainbow trout (Oncorhynchus mykiss). Horm. Behav. 30, 13-21.

Kimwele C.N., T. Kanui, A. Aulic 1992. Effect of recombinant human growth hormone on anorexic Nile crocodiles (Crocodylus niloticus). Comp. Biochem. Physiol. 102A, 553-557.

Kudo H., Y. Tsuncyoshi, M. Nagac, S. Adachi, K. Yamauchi, H. Ueda, H. Kawamura 1994. Detection of thyroid hormones receptors in the olfactory system and brain of wild masu salmon, $O$. masoll, during smolting by in vitro autoradiography. Aquac: Fish. Manag. 25, 171-182.

Le Bail P.-Y., J. Pérez-Sanchez, K. Yao, G. Maisse 1993. Effect of GH treatment on Salmonid growth, study of the variability of the response. $I n$ : Aquaculture, fundamental and applied rescarch. B. Lalhou, P. Vitiello eds. Coast. Estuar. Stud. 43, AGU, Washington DC., 173-197.

Leatherland J.F. 1994. Reflection on the thyroidology of fishes: from molecules to humankind. Guelph Ichthyol. Rev. 2, 1-67.

Martin R.J.M., T.G. Ramsey, R.B.S. Harris 1984. Central role of insulin in growth and development. Domestic Anim. Endocrinol. 1, 89-104.

Mazeaud M.M., F. Mazeaud 1981. Adrenergic responses to stress in fish. In: Stress and fish. A.D. Pickering ed. Academic Press, New York, 49-68.

Milnes R.S., F.J. Leatherland, B.J. Holub 1979. Changes in plasma thyroxinc, triiodothyronine and cortisol associaled with starvation in rainbow trout (Salmo gairdneri). Environ. Biol. Fïsh. 4, 185-190).

Mommsen T.P., E.M. Plisetskaya 1991. Insulin in fishes and agnathans: history, structurc, and metabolic regulation. Rev. Aquat. Sci. 4, 225-259.

Morley J.E. 1995. The role of peptides in appetite regulation across species. Am. Zool. 35, 437-445.

Murat J.C., A. Serfaty 1971. Variations saisonnières de l'effet de la thyroxine sur le métabolisme glucidique de la carpe. J. Physiol. (Paris) 63, 80-81.

Navarro I., M.N. Carneiro, M. Parrizas, J.L. Maestro, J. Planas, J. Gutierrez 1993. Post-feeding levels of insulin and glucagon in trout (Salmo trutta fario). Comp. Biochem. Physiol. 104A, 389-393.

Navarro I., J. Gutiérrez, J. Planas 1995. Estimates of fish glucagon by heterologous radioimmunoassays: antibody sclection and cross-reactivities. Comp. Biochem. Physiol. $110 \mathrm{C}, 313-319$.

Olsson C., G. Aldman, A. Larsson, S. Holmgren 1997. CCK, gastric emptying and stomach motility in the rainbow trout, Oncorhynchus mykiss. First workshop (COST 827) on volontary food intake in fish, Aberdeen (UK), 3-9 April 1997.

Pérez-Sanchez J., H. Marti-Palanca, P.-Y. Le Bail 1994. Homologous growth hormone (GH) binding in gilthead seabream (Sparus aurata). Effect of fasting and refeeding on hepatic GH-binding and plasma somatomedin-like immunoreactivity. J. Fish Biol. 44, 287-301.

Pérez-Sanchez J., J. Smal, P.-Y. Le Bail 1992. Location and characterization of growth hormone-binding sites in the central nervous system of a Telcost fish (Oncorhynchus mykiss). Growth Regulation 1, 145-152.

Peter R.E., T.A. Marchant 1995. The endocrinology of growth in carp and related species. Aquaculture 129, 299-321.

Pickering A.D. 1981. Stress and fish. Academic Press, New York, $367 \mathrm{p}$.

Plisetskaya E.M. 1990. Recent studies of fish pancreatic hormones, selected topics. Zool. Sci. 7, 335-353.

Plisetskaya E.M., V.M. Bondavera, C. Duan, S.J. Duguay 1993. Does salmon brain produce insulin? Gen. Comp. Endocrinol. 91, 74-80.

Reidelberger R.D. 1994. Cholecystokinin and control of food intake. J. Nutr. 124, 1327S-1333S.

Rodgers B.D., L.M. Helms, E.G. Grau 1992. Effects of fasting, medium glucose and amino acid concentrations on prolactin and growth hormone release, in vitro, from the pituitary of the tilapia Oreochromis mossambicus. Gen. Comp. Endocrinol. 86, 344-351. 
Sakamoto T., T. Hirano 1992. Growth hormone receptors in the liver and osmoregulatory organs of rainbow trout: characterization and dynamics during adaptation to scawater. J. Endocrinol. 132, 425-433.

Sankaran H., A. Wong, S.J. Khan, H.V.S. Pecke, E. Raghupathy 1987. Bioassayable cholescystokinin in the brain of the goldfish, Carassius auratus. Neuropeptides 9, 103-111.

Sanson W.T.C. Murphy, D. Robinson, T. Vargas, E. Tau, J.-K. Chang 1996. A 35 amino acid fragment of leptin inhibits feeding in the rat. Endocrinology 137, 5182-5185.

Scanes C. 1995. Growth hormone action, Carbohydrate metabolism. In: Growth hormone. S. Harvey, C.G. Scanes, W.H. Daughaday eds. CRC Press, 371-377.

Scanes C.G., R.M. Campbell 1995. Growth hormone: chemistry. In: Growth hormone. S. Harvey, C.G. Scanes, W.H. Daughaday eds. CRC Press, 1-24.

Sefkow A.J., J.J. Distefano, B.A. Himick, S.B. Brown, J.G. Eales 1996. Kinetic analysis of thyroid hormone secretion and interconversion in the 5-day fasted rainbow trout, O. mykiss. Gen. Comp. Endocrinol. 101, 123-138.

Sheikh S.P. 1991. Neuropeptide Y and peptide YY, major modulators of gastrointestinal blood flow and function. Am. J. Physiol. 261G (Gastrointest. Liver Physiol.) 24, 701-715.

Steiner R.A. 1996. Editorial: Lords and ladies leapin's on leptin. Endocrinology 137, 4533-5434.

Sumpter J.P., P.-Y. Lc Bail, A.D. Pickering, T.G. Pottinger, F.J. Garragher 1991. The effect of starvation on growth and plasma growth hormone concentration of rainbow trout, Oncorhynchus mykiss. Gen. Comp. Endocrinol. $\mathbf{6 3}$, 94-102.

Toguyeni A., F.J. Baroiller, A. Fostier, P.-Y. Le Bail, E.R. Kühn, K.A. Mol, B. Fauconneau 1996. Consequences of food restriction on short-term growth variation and on plasma circulating hormones in Oreochromis niloticus in relation to sex. Gen. Comp. Endocrinol. 103, 167-175.

Vigna S.R., B.I. Fisher, J.L.M. Morgan, G.L. Rosenquist 1985. Distribution and molecular heterogeneity of cholecystokinin-like immunoreactive peptides in the brain and gut of the rainbow trout, Salmo gairdneri. Comp. Biochem. Physiol. :2C, 143-146.

Vijayan M.M., J.I: I eatherland 1989. Cortisol-induced changes in plasma glucose, protein, and thyroid hormone levels, and liver glycogen content of coho salmon (Oncorhynchus kisutch). Can. J. Zool. 67, 2746-2750.

Wedemeyer G.A., B.A. Barton, D.J. McLeay 1990. Stress and acclimatation. In: Methods for fish biology. C.B. Schreck, P.B. Moyle eds. Am. Fish. Soc. Bethesda, Maryland USA, 451-489.

Yao K., P.D. Niu, F. Lc Gac, P.-Y. Le Bail 1991. Presence of specific growth hormone binding sites in rainbow trout (Oncorhynchus mykiss) tissucs: characterization of the hepatic receptor. Gen. Comp. Endocrinol. 81, 72-82. 